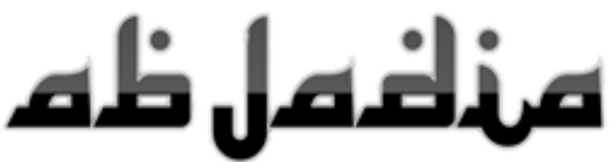

International Journal of Education

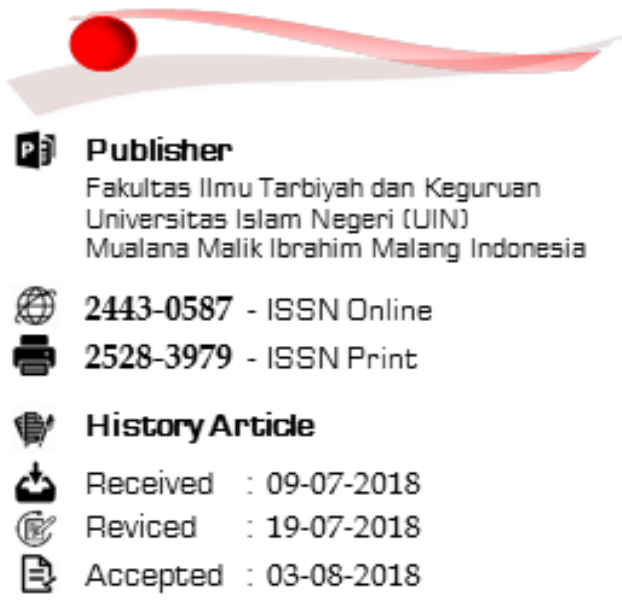

doi) $10.18960 /$ abj.vi2. 5987

http://ejournal.uin-malang.ac.id/index.php/ abjadia/article/view/5987

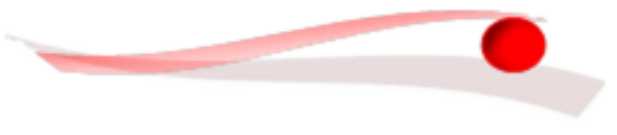

(2) Hamidulloh Ibda
9. Indonesia
(2) STAINU Temanggung
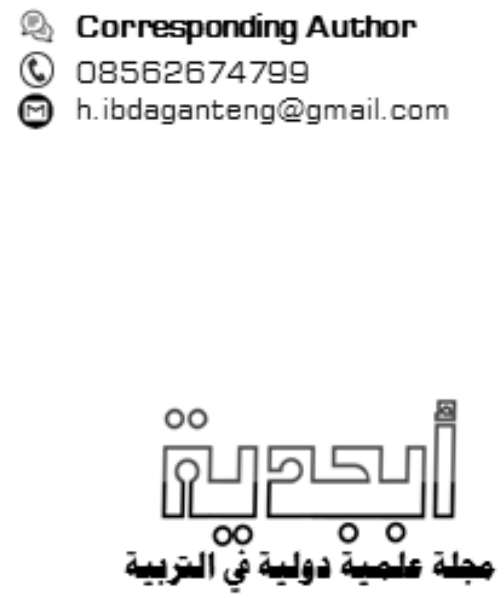

Hamidulloh Ibda

Indonesia

\section{CLASS ASSOCIATION PROGRAM TO PREVENT DELINQUENCY OF ELEMENTARY SCHOOL CHILDREN}

\section{堅, Abstract}

This study aims at describing the class association program in Sampangan 01 Elementary School, Semarang in preventing child delinquency. Delinquency in this study includes physical violence such as hitting friends, harsh words, smoking, hair dyeing, stealing, use narcotics and others. The results of the research, the class association as part of the partnership program for the three centers of education and family involvement in the education unit is very strategic to building families in the success of children's education. In addition, to play a role in preventing juvenile delinquency, the class association mobilizes class independence in designing classrooms and completing class facilities. The significant impact of this class association prevents child delinquency for one semester initially there were 15 children into 3 children, supports the success of learning in schools, synergies between parents and schools, intense face-to-face communication and via telephone, parent and homeroom meetings, and parent classes. The class association also supports schools in carrying out active learning with classroom transparency media to make children comfortable learning from the work of class community members.

Child Delinquency, Class Association, Elementary School

Citation: Ibda, Hamidulloh. (2018). Class Association Program to Prevent Delinquency of Elementary School Children. Abjadia: International Journal of Education, 3(2), 112-127. 


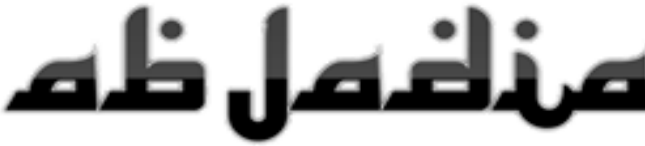 \\ International Journal of Education}

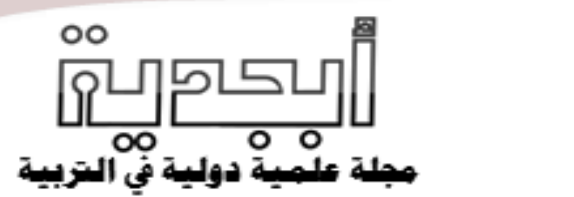

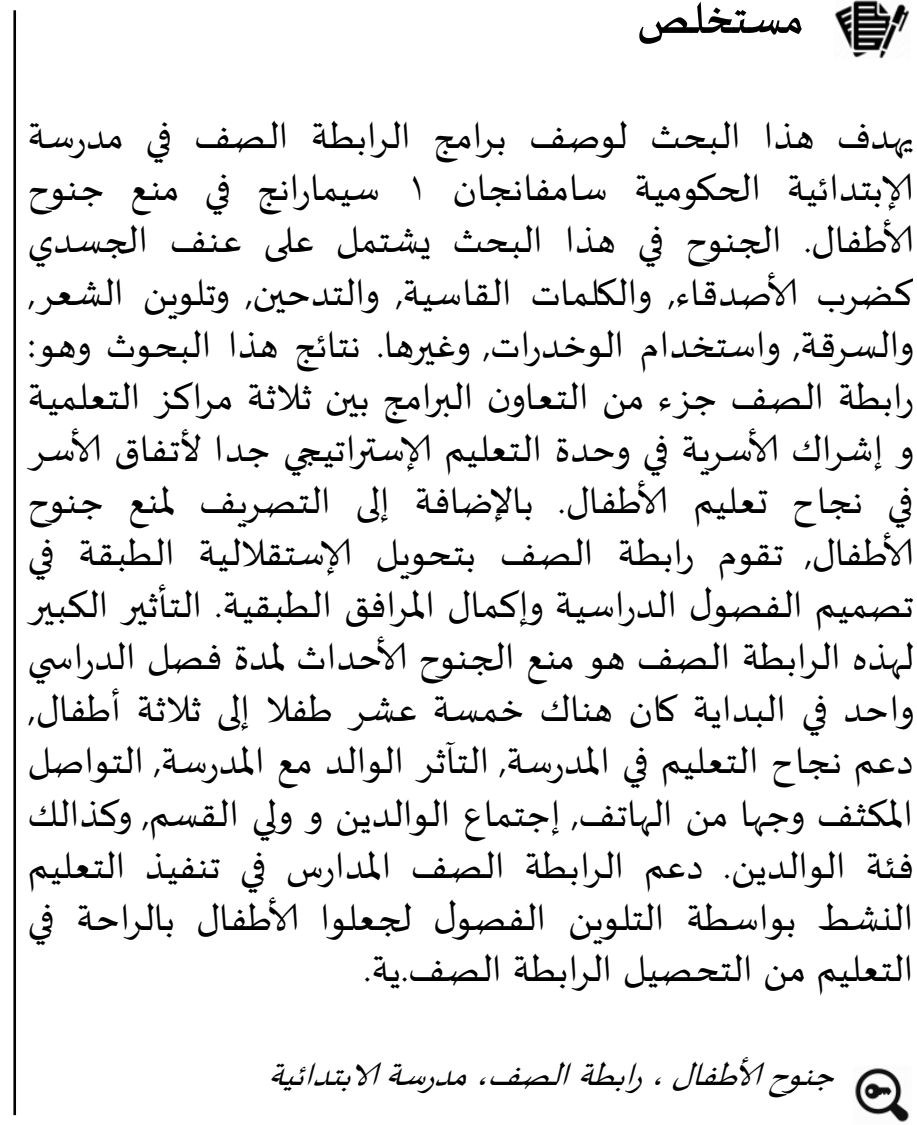

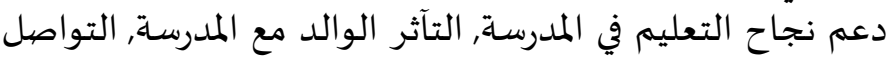

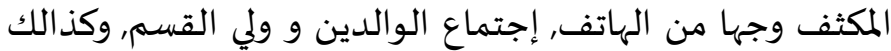

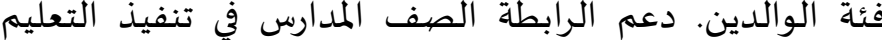

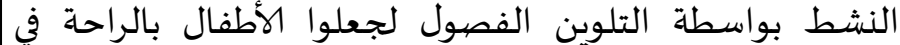
التعليم من التحصيل الرابطة الصف. لصفية. جنوح الوطفال ، رابطة الصفف، مدرسة الاتبدائية

\section{(C) INTRODUCTION}

Delinquency of elementary school children in urban areas is very different from those in the village. Child delinquency in the village is still at a reasonable level, but in urban areas it has exceeded reasonableness because it has been categorized as a criminal. Judging from the shape, Sunarwiyati S (1985) (Sarwini, 2011, p. 244) dividing juvenile and juvenile delinquency into three levels. First, ordinary delinquency, such as fighting, wandering around, skipping school, leaving home without saying goodbye. Second, delinquency which leads to violations and crimes such as driving a car without driving license, taking parental items without permission. Third, special delinquency such as narcotics abuse, extramarital sex, rape and others. From the perspective of law, based on Article 1 Point 2 of Act Number 3 of 1997 concerning Juvenile Courts, qualifying juvenile delinquency as children who commit criminal acts and children who commit acts that are prohibited for children, both according to the laws and regulations according to other legal regulations that live and apply in the community concerned.

As an example of research at Muhammadiyah 15 elementary schools in Surakarta in the 2016-2017 school year, which mentions some student delinquency. Starting from hiding friends' belongings, fighting, being busy, loving toys and not 
paying attention when learning, skipping or not going to school without information, difficult to manage, asking for money from friends, smoking, breaking the rules in the school not wearing uniforms according to the day, late entering school, lying, nosy disturbing his friends, calling his friend's name as the name of his parents, and uploading bad pictures on Facebook (Handayani, 2017, p. 1).

Other research mentions, there are several forms of delinquency in elementary school children. Such as damaging school equipment, crossing dingings, stealing things from friends, fighting during school hours, harshly sending other friends and beating other friends, playing truant, speaking harshly, yelling at the teacher, and others. The results of the research showed that the delinquency was not because the teacher was a majority of women, but because of a lack of parental attention to children's education after they returned home from school, and lack of supervision of children (Satria, 2016, p. vii).

While research at the fifth grade of Kliwonan 2 Elementary School in Masaran, Sragen found a number of mild mischief in children. Such as absent from the midnight prayer congregation, ditching, chatting / busy during class hours, running away from school during class hours, uniforms not in accordance with the rules, not doing schoolwork, not wearing belts and socks, often late to school, cheating, disobeying / refusing, throwing garbage not in its place, and leaving hair (for male students) and nails left to elongate (Rohmawati, 2012, p. 2). This is certainly a hard task for schools and teachers because their status is still students. Do not let their mischief become an indication of the destruction of a nation.

Thomas Lickona (1991) (Dwi Astuti Martianto, 2002, pp. 2-3) argue, there are 10 signs of the destruction of a nation. First, increasing violence in the community. Second, the use of language and words worsens. Third, the influence of groups that are strong in violence. Fourth, increasing self-destructive behavior, such as drug use, drinking alcoholic beverages and free sex. Fifth, the blurring of good and bad moral guidelines. Sixth, the decline in work ethic. Seventh, the lower respect for parents and teachers. Eighth, the low sense of responsibility of individuals and citizens. Ninth, dishonesty. Tenth, mutual suspicion and hatred among others.

In general, child delinquency occurs due to internal and external factors. Internal factors can occur because of personal and family. While the internal environment, association, and technological advancements that make them easy to access the internet which it is not filtered will affect daily behavior. Family factors are very dominant as a cause of delinquency in children, both in the form of physical and verbal violence due to the effects of a less harmonious family.

The family is the first educational institution and parents are the main educators. The reality is that most parents are the least prepared educators. Data shows 
the length of Indonesian Citizens' education is only 8.56 years (Center for Education and Culture Data and Statistics, 2015-2016) or equivalent to grade 3 of Junior High School. This means that in general, parents or prospective parents do not have enough education to become adequate parents in educating their children (Kemdikbud, 2017, p. 1 ). It is very reasonable when there is domestic violence, divorce, which has negative impact on children.

The impacts of domestic violence include children feel fear, confusion, and shocked at seeing violence their parents do. In addition, children tend to be rebellious, rude, do not want to be friends and prefer to be alone. If it is let to be done, it can disrupt the development of children, either physically, psychologically, behavior, or achievements later. The long-term impact on boys is that they will imitate their father's violent behavior. Girls tend to accept violence as a natural thing, so that when they grow up they are more likely to become victims again (Dirjen PAUD, 2011, p. 10)

In Semarang, up to October 2018, the Semarang City Education Office noted that there were 300 students involved in brawls, wild racing, free sex, and drug abuse (Utama, 2018). In January 2018, Public Relations Polrestabes Semarang noted that crime was committed by children of increasing age. Ranging from fights between students to criminal acts that lead to seizure of goods (Aris, 2018).

While in Sampangan 01 Semarang Elementary School, based on the Class I-V Guidance and Special Services Guidance Book for semester 2017-2018, there are a number of cases of child delinquency. Starting from hitting a friend, smoking, ditching, stealing food in a canteen, friends 'money and goods, stealing a friend's bicycle, ngelem (breathing steam glue), polishing hair, abuse, saying rude things to friends and teachers, calling friends with parents' names, revealing clothes female student. The school records that there are 1 to 2 bad children in each class from grades 1 to 6 with a total of 15 children in the even semester of the school year 2017-2018.

From the above theoretical framework, delinquency in Sampangan 01 Public Elementary School is classified as a child delinquency which is dangerous because there are categories that go into criminal acts such as stealing, gluing glue, and sexual abuse to female students. This delinquency must be broken through the synergy and strengthening of schools, families, and communities. The Ministry of Education and Culture has strengthened systems and policies to synergize the role of schools, families, and communities through breakthroughs. One of them is by involving parents in the process of education in formal schools.

The work of teachers (educators) in schools will be more effective if the teacher knows the background of his students who are less advanced in the lesson. Thanks to the collaboration of parents and teachers in schools, the lack of students has been greatly overcome, many ways have been taken to establish cooperation between parents 
and teachers in schools (Wahyuni, 2017, p. 60). This collaboration is a form of implementation of the three centers of education, school-based management, and school committees.

The involvement of parents in children's education has an impact on academic functions at school. The dimensions of parental involvement are divided into the frequency of parent and teacher contact, the quality of parent and teacher interactions, participation in home education activities, and participation in school activities. This pattern contributes to the advancement of children's education and reduces child delinquency (Fendrich, 1999, p. 817).

The involvement of parents in guarding children's education in the education unit is very urgent. One of the objectives is to realize cooperation and alignment of education programs in schools, families, and communities as a center for education in building educational ecosystems that foster the character and culture of achievement of students (Sukiman, 2017, p. 5).

All problems in elementary schools can be anticipated and solutions are sought through internal management of educational institutions. Starting from the elements of teachers, principals, education staff, to school guards. Problems of children not all present or coming from or at school. However, nowadays it comes from the factors of friends, association, community, or the influence of the internet, devices, and cyberspace that are increasingly prevalent.

Synergy between family, school and society is very important, especially in the world of madrasas in elementary school, which can form class associations by gathering teachers, homerooms, guardians of students, school committees, religious leaders, and community leaders who are tasked as educators, supervisors, and education police for children. The learning success of elementary school children is very determined synergy between these elements. If you cannot work together, it will certainly have an impact on the child itself (Ermilasari, Ect, 2019, p. ix).

One program for family involvement in schools is the existence of class association. This program is an implementation of family involvement and strengthening of relations between the three centers of education in formal schools. This program can not only be implemented in urban areas, but also schools in remote villages that can prevent child delinquency.

\section{[Q] RESEARCH METHOD}

This study uses a qualitative research approach. Theoretically, qualitative research is a study that aims to understand the phenomenon of what is experienced by research subjects such as behavior, perception, motivation, action, holistically and by way of descriptions in the form of words, in specific natural contexts and utilizing 
various natural methods (Moleong, 2005, p. 6). This study aims at describing systematically and comprehensively about the form of implementation of the class association program at Sampangan 01 Elementary School, Semarang. The data source of this study is divided into primary and secondary data. Primary data in this study is data that is directly obtained from informants based on interviews in this study, namely people in the structure of the school management, homeroom teacher, student guardian, school committee. While secondary data are about students, teachers, school documents, structural boards, and others.

The data collection techniques are observation, interview, and documentation related to the Sampangan 01 Semarang State Elementary School conducted on December 1, 2018 to December 15, 2018 which examines the activities of the class of the 2018-2019 semester in the academic year. The study explained the class association program that had been carried out in the odd semester in the 2018-2019 school year, starting from June to December 2018 in the Sampangan 01 elementary school in Semarang City.

This study uses data analysis based on descriptive qualitative analysis by presenting factual information obtained from Sampangan 01 state elementary school, which deals with the management of the class community, from coordination, practice of escorting children at home and school, to synergy with teachers / guardians class. The goal is to make a systematic, factual and accurate description or description of the class association program in Sampangan 01 state elementary school which can prevent child delinquency in one semester.

\section{FINDINGS}

\section{Class Association as a Form of Family Engagement}

In language, the community originates from the word of Java "guyub" which means association, unity, cooperation, group and harmony. Whereas the class association is an association of parents or guardians of students with the aim of making children's education successful in educational units.

The class association is a parent association of students in a class that aims to build, grow, and increase participation, care, and responsibility of parents by giving advice, input, in an effort to improve student learning outcomes. The class association aims to create good synergy between teachers / homeroom teachers and parents in improving the quality of elementary school learning (Pratama, 2016, p. 9). Class associations are a form of partnership between school and family that can be done through several activities. First, parent meeting activities. Second, the involvement of 
parents of parents in the child class. Third, the involvement of parents in a joint event. Fourth, there is a child consultation day (Hatimah, 2016, p. 296).

The class association is part of family involvement in formal schools based on Minister of Education and Culture Regulation Number 30 of 2017 concerning Family Engagement in the Implementation of Education, Regulation of the President of the Republic of Indonesia Number 87 of 2017 concerning Strengthening Character Education, and Minister of Education and Culture Regulation Number 20 of 2018 concerning Strengthening Character Education in Formal Education. One form of involvement is the existence of a class association that contains guardians of students or parents of students.

From this basis, Sampangan 01 Public Elementary School created a class association program that was implemented since June 2018. It originated from the problem of delinquency of children present in each class, from grades 1 to 6 which almost every class had bad children who were the source of problems and influence other children.

The class association at Sampangan 01 Elementary School refers to the partnership of the three centers of education. Starting from the synergy of the school with the family, and the community on the basis of mutual cooperation, trust, mutual respect, and concern for the achievement of children by trying to minimize delinquency in the child itself. The implementation of the class association at Sampangan 01 Elementary School aims to support the learning process in schools by synergizing schools, families and communities.

Family involvement carried out by forming a class association at Sampangan 01 Public Elementary School has five objectives according to the government's mandate. First, increasing awareness and shared responsibility between the education unit, family, and society towards the implementation of education. Second, encourage the strengthening of children's character education. Third, increasing family awareness of children's education. Fourth, build synergy between educational units, families, and communities. Fifth, create an educational unit environment that is safe, comfortable and enjoyable (Kemdikbud, 2017, p. 4).

This form of class association activities in Sampangan 01 Public Elementary School refers to the family involvement program in the education unit. First, attend a meeting by the education unit. Secondly, guardian classes. Third, to be a resource for activities in the education unit. Fourth, play an active role in the year-end class stage activities. Fifth, participate in co-curricular, extracurricular activities and child development activities. Sixth, become a member of the school committee. Seventh, active in the activities of the school committee. Eighth, became a member of the violence prevention team. Tenth, active in the prevention of pornography, porno-action, and 
drug, psychotropic and other addictive substances. Tenth, facilitate and play a role in strengthening the character of children in the education unit (Kemdikbud, 2017, p. 6).

The class association model in Sampangan 01 Public Elementary School was conceptualized by referring to the model of involvement of families and communities in educational units made by the government. This model as a manifestation of family involvement in educational units can be seen in the figure below (Sukiman, 2017, p. 13):

\section{Chat 1. Class Association Model}

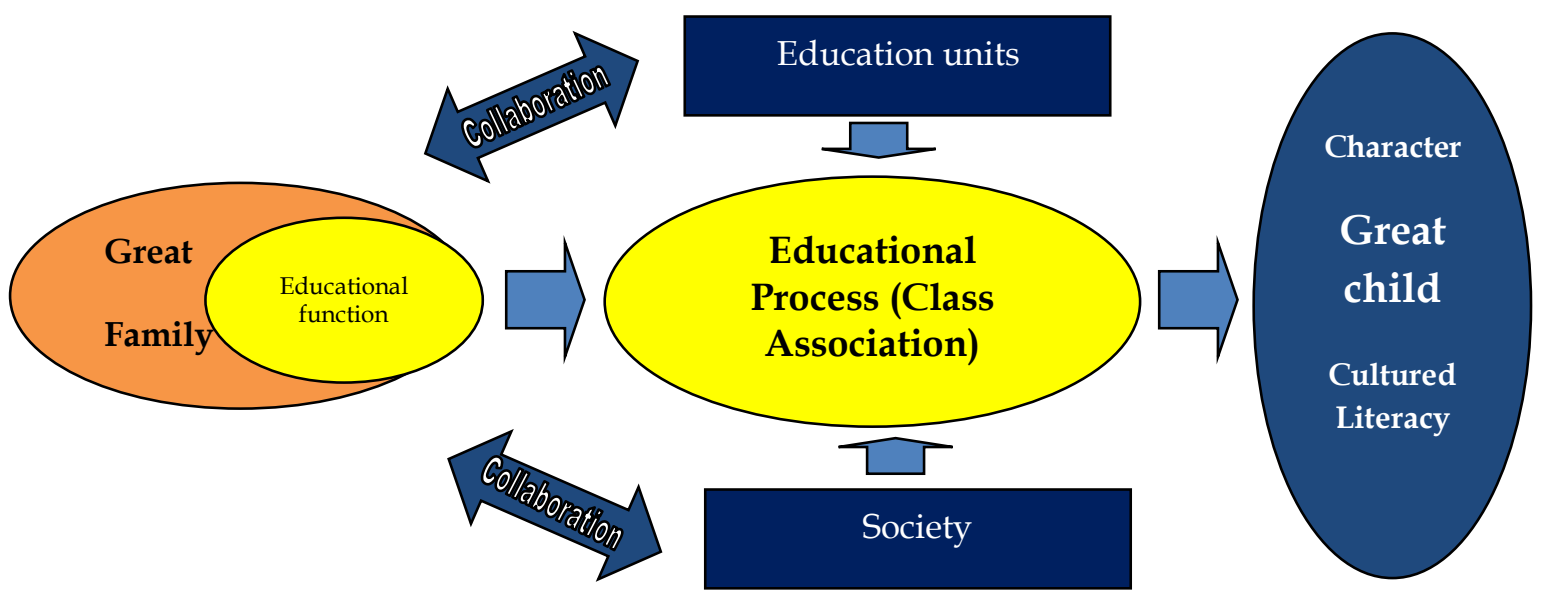

The class association in Sampangan 01 Elementary School is a community or parent / guardian association of students in one study group or class in an education unit in accordance with the rules of the government in this case the Ministry of Education and Culture. The class association at Sampangan 01 Elementary School has many goals and functions to support the implementation of education in the education unit and the success of children's education. The class association also has the role of supporting the strengthening of children's character education, creating an educational unit environment that is safe, comfortable and enjoyable, and prevents child delinquency.

The class association at Sampangan 01 Elementary School was born because many parents both father and mother worked all. The students of Sampangan 01 Elementary School on average only fulfilled the aspects of clothing, food, and board, while the educational nutrition, character, and exemplary were neglected. Moreover, parents come to work already tired, so their time for children is not optimal. When so, the children are far from their parents and they are easily influenced by the environment because parents neglect the development of their own children.

\section{The Role and Function of the Class Association}

The role of the class association in Sampangan 01 Primary School is to support education in the education unit. As part of the tri education center, the class association in each class of parents / guardians has a strategic role in the success of children's 
education. They as small institutions also play a major role in strengthening children's character and avoiding children from delinquency

The role of the class association in Sampangan 01 Elementary School is generally divided into two things. First, synergizing family, school and society. Second, the success of children's education in which there is a child delinquency program. As a medium of partnership organization in the center of education and the involvement of families in children's education, the class association has many roles and functions. They play a role not just as a gathering place, but help the school in making children's education successful in accordance with its education unit.

The formation of class associations in Sampangan 01 elementary school is based on openness, mutual cooperation, family and deliberation. The goal is to make it easier for schools to disseminate learning programs, synergy, and make families comfortable with schools, teachers, and homeroom teachers.

The main function of the formation of class associations in Sampangan 01 Elementary School is to support school programs for the success of predetermined educational quality. This is because so far, parents of Sampangan 01 Elementary School students do not fully support the program or agenda of the school, because they are not institutionally involved. Whereas when invited to join and form class associations, they are active and provide anything including material to design classes by completing classroom equipment that is not feasible.

As a program of the tri-center education partnership and involvement of families in children's education in formal education units, the class association in Sampangan 01 Elementary School has many roles and functions. Class associations in Sampangan 01 Elementary School are formed and have parents or student guardians whose role is to guard children's education. The role of the class association is not just the success of children's education, but also to prevent child delinquency that can occur due to social, technological, and community factors by maximizing face-to-face communication or messaging on WhatsApp in each class.

Parents besides guarding children, they also study organizations in the class associations. Those who are appointed to be chairmen, secretaries, treasurers, section of the division, and coordinators according to their region, feel they are learning more like they are in school because they cannot walk carelessly. This function is especially felt by parents, especially for those who have never participated in an organization or social institution.

\section{jị DISCUSSIONS}

\section{Class Association Program of Sampangan 01 Elementary School}


As a school that implements full-day school, school-based management, 2013 curriculum, and strengthening character education, Sampangan 01 Elementary School, Semarang organizes a class association program in each class, of basic classes $(1,2,3)$ and high class $(4,5,6)$ which amounts to 12 classes because 1 class consists of class A and class B. The association class program is applied in 12 classes to parents from 204 male students and 206 female students with a total of 410 students..

This class association program is implemented with several methods::

1. Meeting with parents twice every semester

2. Following parenting class twice a year

3. The involvement of parents is chosen as the inspiration class speaker

4. Involvement of parents in year-endstage exhibitions

The class association in Sampangan 01 Elementary School was conceptualizing and scheduled according to the partnership guidelines for the three center education and family involvement in education from the Ministry of Education and Culture. The school designed the class association program every beginning of the school year. In the 2018-2019 school year, the first class semester class association program has been implemented, while the even semester has not been implemented and will be held in the next semester which can be seen as the table below:

Table 1. Family Engagement Class Association Program at Sampangan 01 Elementary School, Semarang.

\begin{tabular}{|c|c|c|c|}
\hline Number & Month-year & Program & $\begin{array}{c}\text { Semester / } \\
\text { Academic Year }\end{array}$ \\
\hline 1 & June 2018 & $\begin{array}{l}\text { - First day of school (movement to deliver } \\
\text { school children) } \\
\text { - Parent and homeroom teacher meetings }\end{array}$ & 1/2018-2019 \\
\hline 2 & $\begin{array}{l}\text { September } \\
2018\end{array}$ & $\begin{array}{l}\text { - } \text { Mid semester } \\
\text { - Parent and homeroom teacher meetings } \\
\text { - Parent class }\end{array}$ & 1/2018-2019 \\
\hline 3 & $\begin{array}{l}\text { December } \\
2018\end{array}$ & $\begin{array}{l}\text { - Taking report cards } \\
\text { - Parents consulting children's progress }\end{array}$ & 1/2018-2019 \\
\hline 4 & $\begin{array}{l}\text { January } \\
2019\end{array}$ & $\begin{array}{l}\text { - Parent and homeroom teacher meetings } \\
\text { - Parent class }\end{array}$ & 2/2018-2019 \\
\hline 5 & March 2019 & $\begin{array}{l}\text { - Mid semester } \\
\text { - Parent and homeroom teacher meetings } \\
\text { - Discuss class stage plans }\end{array}$ & 2/2018-2019 \\
\hline
\end{tabular}




\begin{tabular}{|l|l|l|l|}
\hline 6 & June 2019 & $\begin{array}{l}\text { - End of semester / taking report cards } \\
\text { - Year-end class performances } \\
\text { - Giving awards to children and parents } \\
\end{array}$ & - Parents consulting children's progress
\end{tabular}

The class association program in Sampangan 01 Elementary School does not only play a role in preventing juvenile delinquency. However, they are supports schools in carrying out active learning with classroom "aransi" media to make children comfortable learning and all that is left to each class association coordinator. They design fun and educatif images such as puppets, pictures of school children, places of worship, figures of punokawan, and others that children love so that children are comfortable and happy when studying at school.

\section{Implementation of the Class Association in Sampangan 01 Elementary School}

Effectively, the class association program at Sampangan 01 Elementary School took place from June to December 2018 which was programmed before the 2018-2019 school year. The implementation of the class association can be seen in table 2 below:

Table 2. Implementation of the Family Engagement Class Association Program at Sampangan 01 Elementary School, Semarang

\begin{tabular}{|c|c|c|c|}
\hline Number & Month-year & Program & $\begin{array}{c}\text { Semester / } \\
\text { Academic Year }\end{array}$ \\
\hline 1 & June 2018 & $\begin{array}{l}\text { - Parents deliver children, from father / } \\
\text { mother, grandmother / grandfather, } \\
\text { brother, or sibling on the first day of } \\
\text { school as a form of movement to } \\
\text { deliver school children } \\
\text { - Each parent and homeroom teachers } \\
\text { exchange cell phone numbers and } \\
\text { determine class leaders or coordinators } \\
\text { of class association } \\
\text { - The coordinator creates a group on the } \\
\text { WhatsApp network, which consists of } \\
\text { all student guardians } \\
\text { - The coordinator creates a group on the } \\
\text { network, WhatsApp, which consists of } \\
\text { all student guardians and class / } \\
\text { homeroom teachers } \\
\text { - Homeroom teacher makes WhatsApp } \\
\text { group containing students }\end{array}$ & 1/2018-2019 \\
\hline 2 & September & $\begin{array}{l}\text { - Meetings of guardians of students and } \\
\text { homeroom teachers who work together }\end{array}$ & 1/2018-2019 \\
\hline
\end{tabular}




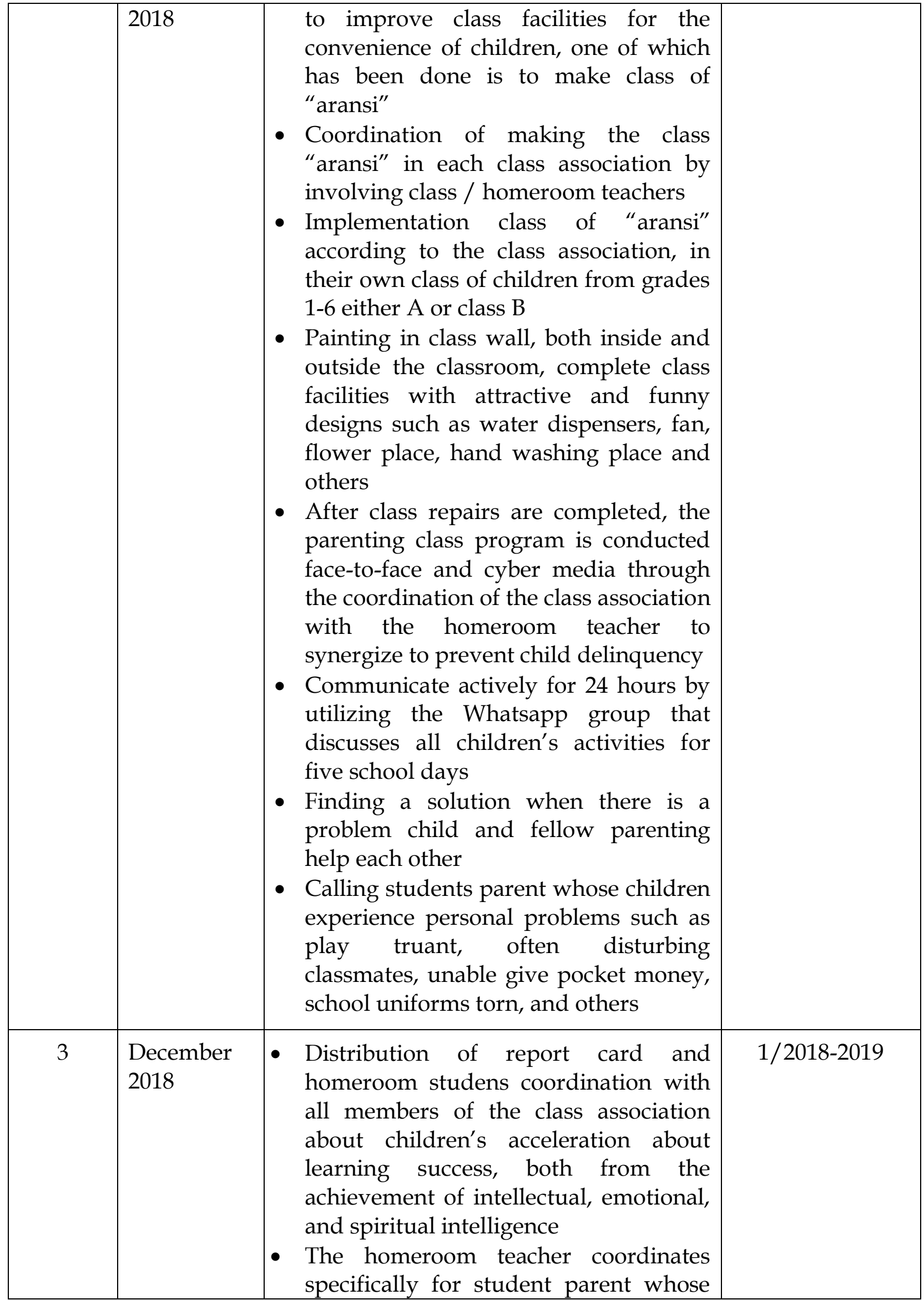




\begin{tabular}{|l|l|}
\hline children have problems in terms of the \\
learning process, character \\
development and delinquency \\
The homeroom teacher gives critics \\
and suggestions on how to guard \\
children outside the school so that they \\
do not commit delinquency \\
The homeroom teacher offers advice on \\
education-based vacation tips so that \\
children keep learning despite the \\
holiday atmosphere \\
The homeroom teacher will deliver a \\
family and community engagement \\
program that will be held in the second \\
semester of the 2018-2019 academic \\
year
\end{tabular}

This program has been formally implemented in schools and even carried out outside of school and outside of working hours. But a more intense activity was at the Whatsapp group which discussed, coordinated, and sought solutions to children's problems and potential delinquency both at school and at home. The homeroom teacher and parents not only report in text, but also send photos and videos of children's activities related to cognitive, affective, and psychomotor development.

\section{Impact of the Class Association Prevents Child Delinquency}

The class association as part of the partnership program of three education centers and family involvement in the children's education unit implemented by Sampangan 01 Elementary School generally has 10 major impacts. First, the class associations in each class from the basic classes $(1,2,3)$ and high class $(4,5,6)$ can support children's success in learning. Second, the class association as a forum for communication and shared interests, makes the family / guardians of students care 90 percent about the fate of children's education, especially in big cities like Semarang, and specially in Sampangan 01 Elementary School.

Third, parents are directly involved in the development of children's education, and do not weighting it on teachers, homerooms, or schools only. Fourth, student parents also become teachers and students, because they also indirectly educate, and get subject matter about positive ways to educate children, and how to educate children in the digital era, as well as ways to prevent child delinquency. Fifth, student parents have the opportunity to be presenters or resource persons in inspiration classes, parenting classes, which are a forum for exchanging ideas, experiences, on how to care for children and prevent delinquency from happening to children. 
Sixth, student parents know all their children's activities at school through the WhatsApp group. When things go wrong, or cheating, parents don't blame the school directly because everything through cyber-controlled with WhatsApp group. Before anything negative happened, the WhatsApp group functioned as a miniature Closed Circuit Television (CCTV) in school. Seventh, student parents are not burdened when there are students who live in class, because before, they are called for consultation, guidance, and coordination about student decisions that deserve to go to class or stay in class.

Eighth, there is wall in classroom attractive, funny, and comfortable class atmosphere because the realization of class "aransi" is handed over to the parents of class members. Classes are comfortable and clean and all facilities are complete because the members of the class association take money contributions and help complete school facilities. Through the class association, each class competes in designing classroom spaces and walls because the school holds a class design competition. Thus, a healthy competition is created in each class association..

Ninth, prevention of delinquency or deviant actions in children, especially in all classes of Sampangan 01 Elementary School, Semarang. Tenth, there is no number of child delinquency that exceeds the limit, because the class association is very intensive and active in escorting all children's activities at school and outside school.

From notes on counseling and special services from grades 1 to 6 , the number of naughty children in grades 1 to 6 who in the even semester of the 2017-2018 academic year has a total of 15 children, until December 2018 it was significantly reduced due to the remaining 3 children. The difficult factor was to stop the delinquency of the 3 children because of his family of thugs, his father selling liquor, did not want to join the class association, and his environment was in a thug village.

Although not yet one hundred percent, the class association program at Sampangan 01 Elementary School has been able to minimize the number of juvenile delinquency even though it has only been running for one meter in the 2018-2019 school year. The three children were still under close guard from the teacher in each class, and the homeroom teacher continued to communicate and took to the field in consultation with his father, mother, grandfather, and even with neighbors and neighborhood heads. The goal is to follow up on the class association program that has not been maximally successful.

\section{CONCLUSION}

The class association program at Sampangan 01 Elementary School has been running for one semester in the odd semester of the 2018-2019 academic year. This 
program is in accordance with the guidelines for involving families and communities in formal education units as a synergy of the three centers of education. The class association program that has finished participating takes early semester children, exchanges telephone numbers, associates classes and administrators, creates WhatApp groups for guardian classes, meetings of all class association members with teachers / homerooms, provides interesting images (aransi) in each class, communicate intensely 24 hours through face-to-face or WhatsApp, meet when sharing report cards, meet and give advice to overcome those who have difficulties, associate delivery programs and meetings for even semester academic year 2018-2019. Although not yet one hundred percent minimize the number of juvenile delinquency, but of the 15 naughty children in the 2017-2018 school year, since the formation of the class association, there are now only 3 children who are still categorized as bad boys..

\section{BIBLIOGRAPHY}

Aris, B. (2018, January). Anak Usia Sekolah Masih Banyak Lakukan Aksi Kriminalitas. Radioidola.Com. Retrieved from radioidola.com/2018/anak-usia-sekolah-masihbanyak-lakukan-aksi-kriminalitas.

Dirjen PAUD. (2011). KDRT dan Pelecehan Seksual Dalam Kehidupan AUD (1st ed.). Jakarta: Direktorat Pembinaan Pendidikan Anak Usia Dini Direktorat Jenderal Pendidikan Anak Usia Dini Nonformal dan Informal Kementerian Pendidikan Nasional.

Dwi Astuti Martianto. (2002). Pendidikan Karakter: Paradigma Baru dalam Pembentukan Manusia. Yogyakarta: BPFE.

Ermilasari, Danik, etc. (2019). Problematika Anak SD/MI dan Solusinya (1st ed.). Semarang: Formaci.

Fendrich, C. V. I. R. P. W. W. J. K. M. (1999). A Longitudinal Assessment of Teacher Perceptions of Parent Involvement in Children's Education and School Performance. American Journal of Community Psychology, 27, 817-839. Retrieved from https://link.springer.com/article/10.1023/A:1022262625984

Handayani, S. (2017). Upaya Guru dalam Menangani Perilaku Kenakalan Siswa di SD Muhammadiyah 15 Surakarta Tahun Ajaran 2016/2017. Universitas Muhammadiyah Surakarta.

Hatimah, I. (2016). Keterlibatan Keluarga dalam Kegiatan di Sekolah dalam Perspektif Kemitraan. PEDAGOGIA: Jurnal Ilmu Pendidikan, 14, 290-297. Retrieved from http://ejournal.upi.edu/index.php/pedagogia/article/view/3878.

Kemdikbud. (2017). Petunjuk Teknis Pelibatan Keluarga pada Penyelenggaraan Pendidikan Anak Usia Dini (1st ed.). Jakarta: Dirjen PAUD dan DIKMAS Kemdikbud.

Moleong, L. J. (2005). Metodologi Penelitian Kualitatif (II). Bandung: PT. Remaja Rosdakarya. 
Pratama, L. (2016). Peran Paguyuban Orang Tua Siswa dalam Pengembangan Sekolah Melalui Manajemen Berbasis Sekolah (MBS) di Sekolah Dasar. Universitas Muhammadiyah Purwokerto. Retrieved from http://repository.ump.ac.id/312/3/BAB II_LANANG PRAMANA_PGSD\%2716.pdf.

Rohmawati, C. (2012). Usaha Guru untuk Mengatasi Kenakalan Anak Kelas V SD Negeri Kliwonan 2 Masaran Sragen Tahun Pelajaran 2011/2012. Naskah Publikasi PGSD, Oktober, 1-13.

Sarwini. (2011). Kenakalan Anak (Juvenile Deliquency): Kausalitas Dan Upaya Penanggulangannya. Perspektif, XVI, 244-251.

Satria, A. (2016). Analisis Tingkat Kenakalan Siswa Sekolah Dasar (Studi Komparatif SD Negeri Balirejo dan SD Muhammadiyah Gendeng Darussalam Yogyakarta). UIN Sunan Kalijaga Yogyakarta.

Sukiman. (2017). Kebijakan Teknis Pelibatan Keluarga dan Masyarakat di Satuan Pendidikan (PAUD, SD, SMP, SMA/SMK, SLB, dan PNF). Sahabatkeluarga.Kemdikbud.Go.Id, pp. 1-54. Retrieved from https://sahabatkeluarga.kemdikbud.go.id/laman/uploads/Dokumen/4684_2017 -04-11/MATERI BIMTEK KEBIJAKAN TEKNIS.pdf.

Utama, D. A. (2018, October). Siswa SMP Nakal Terlibat Seks Bebas dan Narkoba di Semarang Diberi Hipnoterapi. Merdeka.Com. Retrieved from merdeka.com/peristiwa/siswa-smp-nakal-terlibat-seks-bebas-dan-narkoba-disemarang-diberi-hipnoterapi.html

Wahyuni. (2017). Relasi Orangtua dengan Guru dalam Membentuk Karakter Islami Peserta Didik Kelas VIII SMP Negeri 1 Pallangga Kab. Gowa. UIN Alaudin Makassar.

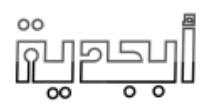

